University of Wollongong

Research Online

Faculty of Social Sciences - Papers (Archive) Faculty of Arts, Social Sciences \& Humanities

$1-1-2017$

Chinese EFL Teachers' Cognition about the Effectiveness of Genre

Pedagogy: A Case Study

Lei-Min Shi

University of Wollongong, Ishi@uow.edu.au

Amanda Ann Baker

University of Wollongong, abaker@uow.edu.au

Honglin Chen

University of Wollongong, honglin@uow.edu.au

Follow this and additional works at: https://ro.uow.edu.au/sspapers

Part of the Education Commons, and the Social and Behavioral Sciences Commons

Research Online is the open access institutional repository for the University of Wollongong. For further information contact the UOW Library: research-pubs@uow.edu.au 


\title{
Chinese EFL Teachers' Cognition about the Effectiveness of Genre Pedagogy: A Case Study
}

\author{
Abstract \\ Developing students' communicative competence became the primary goal of the current College English \\ Curriculum Requirements in 2004 in China. There has been increasing concern, however, that this goal \\ has yet to be realized, particularly in relation to the teaching of writing. This study investigated the \\ potential of a Systemic Functional Linguistics (SFL-) informed genre approach to enhance Chinese \\ students' communicative competence in writing. As teachers' beliefs have a strong impact on the \\ effectiveness of their teaching practice (Borg, 2003), the study examined six Chinese College English \\ teachers' shifts in their beliefs and practices after attending a training workshop in the genre-based \\ approach to writing development. Using pre- and post- workshop interviews and classroom observations \\ and drawing on the analytical frameworks of teacher cognition (Borg, 2003), teacher knowledge \\ (Shulman, 1986) and interactional scaffolding (Hammond and Gibbon, 2005), the study found that \\ professional training in SFL genre pedagogy had a positive impact on teachers' cognition about writing \\ instruction, albeit with one notable constraint; the teachers paid only partial attention to the social \\ purpose of the targeted genre, thus limiting the successful implementation of the pedagogy to a certain \\ extent.
}

\section{Keywords}

case, pedagogy:, effectiveness, study, cognition, chinese, teachers', genre, about, efl

\section{Disciplines}

Education | Social and Behavioral Sciences

\section{Publication Details}

Shi, L., Baker, A. \& Chen, H. (2019). Chinese EFL Teachers' Cognition about the Effectiveness of Genre Pedagogy: A Case Study. RELC Journal: a journal of language teaching and research in Southeast Asia, 50 (2), 314-332. 


\title{
Chinese EFL Teachers' Cognition about the Effectiveness of Genre Pedagogy: A Case Study \\ Leimin Shi • Amanda Baker • Honglin Chen
}

\begin{abstract}
Developing students' communicative competence became the primary goal of the current College English Curriculum Requirements in 2004 in China. There has been increasing concern, however, that this goal has yet to be realized, particularly in relation to the teaching of writing. This study investigated the potential of a SFL- (systemic functional linguistics) informed genre approach to enhance Chinese students' communicative competence in writing. As teachers' beliefs have a strong impact on the effectiveness of their teaching practice (Borg, 2003), the study examined six Chinese College English teachers' shifts in their beliefs and practices after they were provided with workshop training in the genre-based approach to writing development. Using pre- and post- workshop interviews and classroom observations and drawing on the analytical frameworks of teacher cognition (Borg, 2003), teacher knowledge (Shulman, 1986) and interactional scaffolding (Hammond and Gibbon, 2005), the study found that professional training in the SFL genre pedagogy had a positive impact on teachers' cognition about writing instruction, albeit with one notable constraint; the teachers paid only partial attention to the social purpose of the targeted genre, thus limiting the successful implementation of the pedagogy to a certain extent.
\end{abstract}

\section{Key words}

Teacher cognition, genre pedagogy, CLT, College English, writing competence

\section{Introduction}

CLT as the Mandate of College English Curriculum 
Developing students' overall communicative competence through communicative language teaching (CLT), a core concept underlying CLT (Hymes, 1972), has become a principal goal driving English curriculum innovations in many Asian (EFL) countries (e.g., Hardman and A-Rahman, 2014; Rozimela, 2005). In China, for example, developing students' communicative competence was mandated in the national College English (CE) Curriculum Requirements (CECR) in 2004. The CLT approach was introduced as a vehicle to transform English language teaching in China from its traditional focus on grammar translation to a communicatively oriented curriculum with its focus on enabling learners to communicate successfully in authentic social contexts (Gao and Huang, 2010). However, there has been increasing concern that, even after more than two decades, this goal has yet to be realized, especially in relation to writing competence (Hu, 2002; You, 2004b).

This concern has led to the criticism that the CECR may be "more a decoration than a practical instruction to teaching" (Gao and Huang, 2010: 83). Support for developing students' writing competence has in particular been deemed inadequate because writing instruction in CE classes has had a strong focus on linguistic accuracy and final written products as driven by the $\mathrm{CE}$ test $\left(\mathrm{CET}^{1}\right)(\mathrm{Gao}, 2007)$. In addition, the models of language use in the teaching of writing are subjected to criticism due to teachers' adoption of traditional and un-theorised approaches to writing instructions (Tian, 2005; You, 2004b). Thus, there is an urgent need for empirical investigations into effective pedagogical practices to facilitate the development of students' writing for achieving social purposes.

\section{Genre Approach Worldwide and in China}

A significant body of EFL literature in writing discusses several distinguished approaches to the teaching of writing (e.g. Hyland, 2003; Wang, 2013). Of these, the 'product'

\footnotetext{
${ }^{1}$ the assessment system of CE, a nationwide large-scale standardized test administered by the National CE Testing Committee on behalf of the Ministry of Education launched in 1987 (Cheng, 2008; Jin, 2011)
} 
approach has been most dominant in China (Gao, 2007). Its lack of success in improving students' writing competence, however, suggests that an approach better suited to developing students' communicative competence in this area would be more appropriate. This study examines the potential of a SFL-informed (Systemic Functional Linguistics) genre approach to address this need. Focusing on language as meaning making resources, the SFL genre approach provides "teachers and learners with a means of exploring language use within a framework of cultural and social purpose" (Burns, 2001: 200).

Underpinned by a social cultural and social semiotic approach, the SFL-informed genre pedagogy offers a three-stage cycle of Modelling, Joint Negotiation of Text, and Independent Construction of Text (Callaghan and Rothery, 1988) where learning occurs through guidance and interaction in the context of shared experience (Derewianka, 2003; Martin, 1999). This socially-oriented focus is consonant with the CLT's focus on fostering students' communicative competence. Recent studies have demonstrated the value of SFL genre pedagogy in supporting students' writing development in many EFL contexts worldwide, such as in Indonesia (Emilia, 2005; Rozimela, 2005), Thailand (Chaisiri, 2010; Krisnachinda, 2006), Taiwan (Chen and Su, 2012), and Japan (Myskow and Gordon, 2009). This pedagogy may offer a useful means to develop Chinese students' writing abilities as well.

However, relatively little empirical research has examined the effectiveness of genre pedagogy in the Chinese context. Most of the studies were primarily theoretical, involving only discussions of the potential benefits of various writing pedagogies to enhance students' writing competence (e.g. Deng, Chen, and Zhang, 2014; Hu, 2007; Qian, 2010). Among them, some have advocated the use of the SFL genre approach (e.g. Chen and Su, 2012; Huang, 2001; Ji, 2009), but only two empirical studies have been carried out in Chinese contexts. In Taiwan, Chen and Su's (2012) study of 41 students' writing development observed that SFL 
genre pedagogy was effective in enhancing students' overall summarising skills in writing a narrative source text. They argue that this pedagogy contributed to the broader development of learners' overall writing competence. Furthermore, Wang (2013) investigated the effectiveness of the SFL genre pedagogy, focusing specifically on students' perceptions. She found explicit instruction had a positive effect on learners' genre knowledge. In addition, the study found that explicit instructions improved students' genre awareness, their writing quality, and informativeness of their writing marked by higher lexical density, which represents a feature of written texts. These studies provide valuable insights into the potential effectiveness of genre pedagogy; however, none have investigated the impact of teachers' cognitions - "what teachers know, believe and think" (Borg, 2003: 81) - on the implementation of SFL-based curriculum. Research into teacher cognition (TC) has consistently shown that a success factor contributing to the implementation of a curriculum innovation is teacher's beliefs and knowledge about the curriculum. Essentially, teachers' beliefs drive their classroom practices (Richardson, 1996) and thus determine the degree to which they adopt, adapt or reject the implementation of any new curriculum. Therefore, an examination of teachers' cognitions is important if genre pedagogy is to be successfully introduced into any curriculum (Nation and Macalister, 2010).

\section{TC and Educational Changes}

However, numerous factors can have an impact on TCs toward the implementation of new curriculum. Their beliefs, and thus classroom practices, are shaped by complex contextual factors and teachers' educational experience. Many studies have identified both consistent and inconsistent relationships between TC and teaching behaviours (e.g. Baker, 2014; Borg, 1998; Rahimi, 2014; F. Zhang and Liu, 2013). Certain contextual factors (e.g. teachers' workloads, the assessment system, large sized classrooms) have repeatedly been 
identified as having critical influences on Chinese EFL teachers' cognition and practices (e.g. Du, 2002; Kang and Cheng, 2014; Peng, 2011). At the same time, researchers point to the powerful influence of teachers' educational experience, namely 'schooling' (Farrell and Lim, 2005; Orafi and Borg, 2008) and 'professional coursework' (Baker, 2014; Borg, 2001) on teachers' application of their beliefs into actual teaching practices. For instance, Orafi and Borg observed the impact of teachers' own learning experience on the degree to which teachers implemented a new curriculum. They found that the extent to which the teachers adopt the new curriculum depended on the teachers' beliefs about its feasibility in their teaching context. Similarly, in China, Wang and Gao (2008) and Wu (2001) found that teachers' knowledge and learning experiences exert a strong impact on effective English instruction in their classrooms.

Considering the important role of $\mathrm{TC}$ in teaching practice and innovation and the demonstrated usefulness of the SFL genre pedagogy in diverse EFL contexts, the current study examined the value of this pedagogy by investigating the following research questions:

1) How do Chinese EFL teachers view the effectiveness of SFL genre pedagogy?

2) How do Chinese EFL teachers use SFL genre pedagogy to support their students' learning of writing in College English classes?

\section{Research Design}

This case study research (Yin, 2003) was undertaken in CE classes in the Foreign Language Department of a university in China. Purposeful sampling (Gall, Gall, and Borg, 2007; Patton, 2002) was used to select teachers who were teaching Year Two CE, which is the year when a focus on writing is most prevalent in the curriculum. Year Two CE Teachers with a Master's degree and at least five years teaching experience were chosen as focusing on experienced teachers would ensure more reliable data of their typical teaching practices were 
obtained. As a result of a purposeful sampling, six out of $25 \mathrm{CE}$ teachers met the selection criteria and volunteered to participate in the research. The figure below outlines the data collection procedure:

Figure A. Data Collection Procedures.

Pre-workshop phase

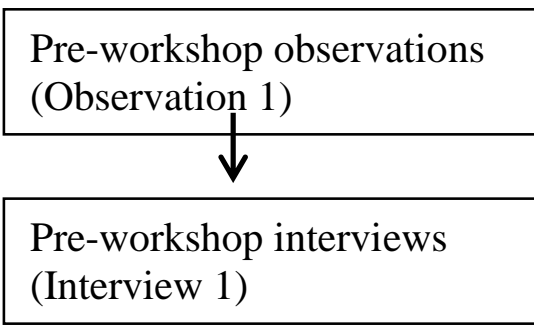

Post-workshop phase

Post-workshop observations (Observation 2)

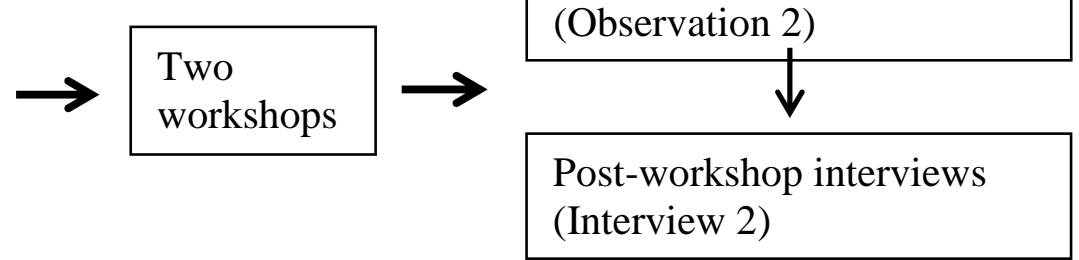

As shown in Figure A, each teacher participated in two semi-structured interviews (see Appendix A for interview questions) and two classroom observations that were conducted by the first author in two separate phases, namely pre- and post-workshop phases. The 30minute interviews took place with each teacher both before (Interview 1) and after (Interview 2) the workshops respectively. Interview 1 (Int 1) aimed to investigate the participants' initial knowledge of curriculum, writing pedagogy, students, and teachers' educational background and professional experiences. Interview 2 (Int 2) explored the teachers' perceptions towards SFL genre pedagogy after using it in their classrooms. Following the same observation protocol (see Appendix B), the first observation provided a snapshot of the teachers' typical teaching practices whereas the second gave insights into how the teachers employed the SFL genre pedagogy in the classroom. All interviews and observations were audio-recorded.

Teachers participated in two workshops (3 hours each) to develop their knowledge about the genre pedagogy. In the first workshop, teachers were introduced to theoretical concepts underpinning the SFL genre approach and its pedagogical model (e.g., scaffolding, zone of promimal development, mediation), including making connections between their own classroom experiences and discussing and modeling their pedagogical values in supporting 
students' learning development. In the second workshop, teachers applied this knowledge through collaborative negotiation between teachers and the researcher in constructing a lesson plan for teaching a target genre in their own classrooms.

The teachers' overarching lesson designs were structured around the SFL genre model consisting of the three stages of the SFL genre model, comprising Modelling, Joint Negotiation of Text, and Independent Construction of Text (Callaghan and Rothery, 1988). The model text features the topic 'Online Shopping' in the Discussion Genre. For the Modelling Stage, the teachers planned how to develop their students' understanding about the content, schematic structure of the text, and how language features work together to form the target genre. Due to classroom time constraints, only the key language features of simple present tense and conjunctions were focused on in the lesson plan. The Joint Negotiation of Text stage involved, the teachers planned to ask students to constructing a new Discussion Genre text on 'Online Entertainment' with the support of peers or their teachers. Guided by Hammond and Gibbons' (2005) notion of interactional scaffolding, the teachers and the first author discussed strategies for supporting students during the Negotiation stage. In the second workshop, teachers role-played (as a teacher and five students) a classroom situation in which they jointly constructed a text on the topic 'Online Entertainment', along with the teacher providing immediate feedback on students' contributions to the joint construction. Different interactional scaffolding strategies, such as elaboration, elicitation, recapitulation, recast, rejection and confirmation (Hammond and Gibbons, 2005), were modelled for the teachers to use when giving feedback. In the final stage, the teachers provided students time to individually construct a new Discussion Genre text on 'Recreational Activities'.

Following data collection, all recorded interviews and observations were transcribed and analysed thematically, looking for patterns within the data, especially as they related to 
Borg's (2003) model of TC, Shulman's (1986) model of teacher knowledge (specifically curricular, subject matter and pedagogical knowledge) and the concept of interactional scaffolding (Hammond and Gibbons, 2005). To ensure reliability, the coding of classroom interaction records was discussed with the two co-authors of this article. Our analysis of classroom interactions was focused on forms of interactional scaffolding teachers provided to develop students' control of language. The common types of interactional support, according to Mercer (1995) and Hammond and Gibbons (2005), can be provided through elaboration, elicitation, recast, rejection, confirmation and recapitulation. Through elaboration, the teacher requests further information to push students to produce more refined responses. Elicitation is employed to provide prompts for the students to ensure participation. Recast is often applied to reformulate students' contribution into more appropriate utterances (Hammond \& Gibbons, 2005) to model appropriate choices. Rejection or Confirmation serves to indicate the teacher's response to students' contribution while recapitulation functions to summarize the main points at the end of the interaction.

\section{Findings and Discussion}

This section first discusses teachers' initial cognition about writing instruction both before they were introduced to the SFL genre pedagogy in the workshops and after they implemented their genre-based lesson plan in the classroom.

\section{Teachers' Initial Cognitions and Practices}

\section{Pre-workshop interview findings}

From the perspective of the teachers' curricular knowledge, writing received limited attention in comparison to other skills. For most teachers (Amy, Cathy, Jane and Mike), reading was the most essential language skill. Mike, for example, stated that "reading ability must be the most important" (Mike, Int 1); Amy emphasized "reading is the basic skill of the 
others" (Amy, Int 1). The teachers' belief in reading as a vital skill did not, however, align with the current CECR's goal to develop learners' overall communicative competence. The teachers' focus on reading, instead, resonated with the previous national CE curriculum. As research has shown, teachers are less likely to implement innovations in their classrooms if curriculum innovations fail to align with their established beliefs (Orafi and Borg, 2008). Hence, the misalignment between teachers' beliefs and the current CECR goal may be a key factor underlying the unsuccessful implementation of the CECR innovation, and also explain why writing receives unequal status in the classroom.

From the perspective of subject matter content knowledge, the teachers believed that writing instruction should cover all of the following: writing techniques for test purposes, text structure, language features and development of argumentation or ideas. In fact, writing for test purposes was considered an essential teaching focus by most teachers (Amy, Cathy, Jane and Kate). Cathy explained that, "because the writing style of tests is there, I normally follow its goal to teach students how to succeed in the tests...the way of connecting between paragraphs and the organization of the whole articles" (Cathy, Int 1). Teachers' concerns about test-taking strategies support findings from previous research (Chu and Gao, 2006; You, 2004a).

The rigid text structure of Introduction, Body and Conclusion is the teachers' second concern regarding content knowledge in writing instruction. This was consistently reflected in their teaching practice. The teachers all stated that a text needed to contain an Introduction, Body and Conclusion. For example, Mike asserted: "writing instruction focuses on ...the structure of Introduction, Body and Conclusion" (Mike, Int 1). He was observed to use a few model texts to explain 'what' and 'how' of these three components when writing texts of Argument Genre. However, none of the teachers delved deeper into the social purpose behind 
the structure of the text, as advocated by genre theorists (Derewianka, 2003; Hyland, 2003; Martin, 2009), instead presenting it as a rigid structure that the students were expected to follow.

In relation to subject matter about language features, the teachers placed greater importance on coherence and grammar. Teachers highlighted their students' weakness in using appropriate language forms, especially conjunctions (Amy, Jane and Mike), and achieving grammatical accuracy (Amy, Mike, Kate and Patty). For example, when interviewed, Kate and Patty explained how they directed students to rewrite augmentation topics in order to address grammatical errors. Similarly, Mike demonstrated efficient use of transitional devices on his PowerPoint slides when observed.

Finally, the teachers valued the development of argumentation and meaningful expressions and they considered these features to be a common student weakness (Amy, Jane, Kate and Mike). Thus, teachers like Cathy focused on improving students' logical expression of ideas in their topic sentences. That said, the primary focus in all lessons still remained on how to achieve accurate grammatical expression. Greater emphasis was placed on correcting errors in students' written texts rather than on developing their argumentation. This dominant focus on grammatical accuracy, however, aligns with the teachers' desire to prepare students for the CET, a critical exam in the Chinese college system.

This test-driven orientation to teaching resulted in a strong focus on grammatical accuracy and the rigid three-part structure used for argumentative texts. These findings resonate with You's (2004a) earlier observation that Chinese teachers' predominant concern focuses on grammatical forms and test-taking skills. This finding may indicate a gap between teachers' curricular and content knowledge in relation to the goal of the CECR or teachers' strong belief in test-driven teaching, both highlighting the urgent need of training teachers to 
enhance their knowledge and beliefs about the development of communicative competence as fundamental to the current goals. This need becomes even more apparent in the subsequent discussion of the teachers' pedagogical knowledge.

\section{Pre-workshop observation findings}

As a demonstration of the teachers' pedagogical knowledge, observations of the teachers' pre-workshop lessons indicated that all six teachers followed a traditional teacher-centred approach as opposed to the CLT/student-focused teaching practices advocated in the CECR. Classroom observations in particular revealed that teachers' explanation dominated the majority of classroom time, leaving little time for student-student interaction to support the development of their writing competence. These findings are not surprising, however, as interview data indicated that, except for completing a writing skill course as a part of their Bachelor and Master's degrees, no teacher had received any professional training in writing pedagogy. These findings reflect Chu and Gao's (2006) findings that the teaching of English writing in many Chinese universities is through teachers' "personal experience and the individual's professionalism" (p.38) instead of systematic approaches based on current writing theories. Teachers' pedagogical knowledge was particularly apparent in their reported cognition about classroom interactions and observed use of model texts.

All teachers advocated the importance of employing different types of classroom interactions in their teaching, such as teacher to student (T-S) or group work/pair work (S-S). However, pre-workshop classroom observations only showed one group discussion in evidence (in Kate's class). Apart from this one S-S activity, randomly asking individual students to answer questions (T-S interaction) was the only interaction style observed. In terms of opportunities provided for T-S participation, the numbers of times varied considerably across the six classes (see Table A). Most teachers (Amy, Cathy, Jane and Patty) 
only interacted with five to 10 individual students throughout the pre-workshop observations. Kate, however, interacted with 21 out of 25 students in her class. Mike's teacher talk, in comparison, dominated the entire lesson. Although the quality of teacher talk was not investigated, the quantity of interaction activities at least indicates the effort that teachers made to incorporate (or not) T-S and S-S interactions. These limited classroom interactions may consequently account for the underdevelopment of students' writing competence in China.

The use of model texts in classroom practice was another dominant component of the teachers' pedagogical knowledge. These texts, however, were mainly used for the purpose of imitating and improving language accuracy, and not for achieving any communicative purpose. Mike argued: "All those basic expressions start from imitating others...[students] learn to express themselves by imitating to fulfil their own writing" (Mike, Int 1). Classroom observations showed that model texts were used to improve students' awareness of syntax or grammatical accuracy, especially in the case of Cathy and Jane. The teachers' beliefs about writing instruction thus reflected the traditional product-oriented approach to writing, with its primary focus on the mechanical aspects of writing (Hyland, 2003; Richard, 1985). This finding supported earlier research highlighting the popularity of the product approach in China (Gao, 2007; Qian, 2010; Yan, 2010; Y. Zhang, 2006), which has partly contributed to the underdevelopment of students' writing competence.

\section{TCs and Practices after the SFL Pedagogy Training}

The above discussion provides a springboard for subsequent discussion of the emerging changes in the teachers' beliefs and practices following the SFL genre pedagogy workshops. The teachers' cognition about the new pedagogy was examined specifically in relation to integral components of the workshop training, namely the three-stage teaching-learning cycle 
(focusing on the stages of Modelling and Joint Negotiation of Text) and other fundamental features, including interactions, scaffolding strategies and language functions.

\section{TC about the Modelling stage}

Overall, all six teachers valued using the Modelling stage to teach writing and to develop their students' ability to learn appropriate text format in particular. Modelling is a "concrete, more targeted and systemic" method (Amy, Int 2). Although most of the teachers used 'modelling' to various degrees prior to the training, they placed even greater importance on this stage following the training. Mike explained:

What I introduced to [my students] before [the SFL training] may be too general. Text structures always include Introduction, Body and Conclusion regardless of the differences between various text types... On the contrary, modelling makes the concept of schematic structure very clear. If they encounter similar expressions, similar articles or writing topics of this text type in the future, it'll be easier for them to carry out... (Mike, Int 2)

Mike's foci on "general" text structure demonstrated what Callaghan and Knapp (1989) refer to as a preliminary understanding of the features of schematic structure. In the SFL genre approach, however, it is through the stages within a schematic structure that a genre moves forward to achieve its social purpose (Callaghan and Knapp, 1989). Mike's realization that his previous attention to the communication purpose of text structure was lacking indicated that the workshop training served to expand his understanding of the functional orientation of schematic structural features. In addition, the six teachers perceived explicit deconstruction of model texts to be beneficial for students particularly in regard to the specific language features of the Discussion Genre. Kate commented that "Students used to write just one sentence to state the merit after the conjunction of 'first' without elaboration...deconstructing a model text must have brought them intuitive feeling. They may have benefited from understanding how moves were realised by sub-moves, phases." 
(Kate, Int 2). From Kate's perspective, modelling helped students to develop their understanding of the language features (e.g. conjunctions) when producing a Discussion Genre text.

However, despite their enhanced pedagogical knowledge of modelling, the teachers demonstrated limited growth in their understanding of the importance in emphasizing social communication purposes when teaching students how to construct texts. As illustrated in his statement above, Mike paid no attention to how schematic structure contributed to the social purpose of a text. His belief mirrored his earlier focus on final writing products and using of appropriate language forms in particular. Similarly, Patty stated: "For students, Argumentation is Argumentation... When using the term Discussion Genre to talk about this type of text, they may not be able to respond quickly..." (Patty, Int 2). Since communication purposes are integral to text type, Patty's statement suggests that she doesn't believe in the necessity for explicit explanation into the social purpose underlying text construction. Moreover, from Patty's perspective, the Discussion Genre was synonymous with Argumentation, indicating her belief that the production of these two types of genres achieved the same social purpose. However, researchers argue that the Discussion Genre gives weight to both sides of an argument while Argumentation aims to support only one viewpoint (Callaghan and Rothery, 1988; Derewianka, 1990). Thus, Patty’s misunderstanding of the two genres reveals a gap in her subject matter content knowledge. Despite the workshop training, her pre-existing belief that these two genres share the same social purpose remained unchanged.

\section{TC about the Joint Negotiation of Text stage}

With regard to the Joint Negotiation of Text stage, all teachers reported having strong beliefs in the usefulness of this stage for the purpose of developing students' ideas for 
argumentation; however, factors such as students' participation level, teachers' inability to provide immediate feedback to all students and large class size directly constrained the successful implementation of this stage. Most teachers viewed the value of this stage in its potential to provide students with opportunities to exchange ideas and to access additional knowledge from peers. Amy, for instance, explained that "Every student has various thoughts; they can enhance their own thoughts by constructing jointly [which helped them to] consider an issue comprehensively" (Amy, Int 2). Patty stressed: "students can exchange their information...discuss...finally can make their decisions on how to make a better elaboration" (Patty, Int 2). However, the teachers also suggested several factors that require further consideration. Firstly, the teachers believed that the students' level of participation had a direct influence on the effectiveness of the stage (Cathy, Mike and Patty). "Students' cooperation is the key to success in this stage" (Mike, Int 2). Secondly, teachers' immediate supervision and feedback were required (Amy and Cathy), with Cathy noting that there is an expectation that, "as soon as finishing writing in groups, we must provide [students] with feedback, a response straight away" (Cathy, Int 2). Additionally, class size had an impact on teachers' beliefs. Jane highlighted that "it depends on the class size. The outcome would be better with a class of about 30 students" (Jane, Int 2). Jane's concern seems to be consistent with many researchers' arguments (Du, 2002; Hu, 2002; Yü, 2001; You, 2004b) that large class size is a barrier to adopting the learner-centred teaching mode inherent to the communicative approaches to language teaching.

However, despite their reservations, some of the teachers successfully implemented the Joint Negotiation of Text stage in their lessons. After their students collaboratively constructed the text on "Online Entertainment", Kate and Mike provided students with immediate feedback on their work. However, other teachers struggled with implementing this 
stage. For example, Cathy incorporated a group discussion involving joint negotiation of the text, but failed to follow up with providing feedback on the students' progress. Missing this critical step thus limits the development of the learners' writing competence as classrooms with high support are where learning happens best (Hammond and Gibbons, 2005). However, Cathy's students didn't seem to have been effectively supported with immediate feedback. Finally, in the case of Amy and Jane, the entire Joint Negotiation stage was omitted from their observed lessons, thus further limiting the potential for growth in the students' writing competence.

\section{TC about interactions and scaffolding strategies}

Subsequent analysis of the teachers' beliefs about classroom interactional activities showed some inconsistencies. All six teachers believed in the value of using diverse interactional activities and, in fact, most teachers generally thought they had successfully assisted their students through classroom interactions. Cathy, for example, reflected "I feel my interactions with students were successful" (Cathy, Int 2). Analysis of observed classroom interactions, however, revealed varying results. Observations demonstrated differing levels of consistency between the teachers' T-S interactions and related interactional scaffolding strategies indicated various levels of consistency and their stated beliefs. Clear changes were evident in terms of the frequency of the T-S interactions (occurrence) and the employment of associated interactional scaffolding strategies (quality and quantity). As shown in Table A, in the post-workshop classroom observations, most teachers provided more opportunities for T-S interactions than they did in pre-workshop lessons. Among them, Mike's change was most notable. He enabled $14 \mathrm{~T}-\mathrm{S}$ interactions in his post-workshop lesson, whereas prior to the workshop, his lesson consisted entirely of teacher talk. Such a dramatic 
change in increased T-S interactions indicates that students received greater opportunities for enhancing their communicative competence.

Table A. Occurrence of T-S Interactions.

\begin{tabular}{|l|c|c|c|c|c|c|}
\hline $\begin{array}{l}\text { Occurrence of T-S interactions } \\
\text { (Student number of each class) }\end{array}$ & $\begin{array}{l}\text { Amy } \\
(40)\end{array}$ & $\begin{array}{l}\text { Cathy } \\
(49)\end{array}$ & $\begin{array}{l}\text { Jane } \\
(29)\end{array}$ & $\begin{array}{l}\text { Kate } \\
(25)\end{array}$ & $\begin{array}{l}\text { Mike } \\
(49)\end{array}$ & $\begin{array}{l}\text { Patty } \\
(40)\end{array}$ \\
\hline $\begin{array}{l}\text { Invited individuals for T-S interactions in pre- } \\
\text { workshop teaching }\end{array}$ & 5 & 10 & 8 & 21 & 0 & 6 \\
\hline $\begin{array}{l}\text { Invited individuals for T-S interactions in post- } \\
\text { workshop teaching }\end{array}$ & 6 & 14 & 17 & 25 & 14 & 2 \\
\hline
\end{tabular}

The teachers' adoption of diverse interactional scaffolding strategies provided additional evidence of change in their beliefs. As illustrated in Table B, most teachers demonstrated a significant increase in their use of interactional support strategies in their post-workshop lesson. In particular, Mike's and Kate's T-S interactions warrant close attention. Mike not only made the most substantial changes in his use of T-S interactions, he also used a greater variety of interactional scaffolding strategies to assist students. These changes align with his belief in the value of Joint Negotiation of Text. In the case of Kate, she initiated $25 \mathrm{~T}-\mathrm{S}$ interactions - the most interactions of all the teachers in the post-workshop observations, although this represents an increase of only four interactions over the pre-workshop lesson. Her use of interactional scaffolding strategies demonstrated a remarkable increase, rising sharply from 29 to 81 occurrences. As such, the students in Kate's class were the most engaged of all students in the study based on the diversity and quantity of interaction activities. Overall, for these two teachers, Mike's significant changes in his post workshop teaching may reflect his open-minded attitude to the introduction of the genre pedagogy, while Kate's consistent teaching behaviour clearly aligned with her strong belief in the pedagogical value of interactions in supporting students. 
Table B. Identified Interactional Features in Classroom Discourse.

\begin{tabular}{|c|c|c|c|c|c|c|c|c|c|c|c|c|c|c|}
\hline \multirow{2}{*}{$\begin{array}{l}\text { Interactional } \\
\text { scaffolding } \\
\text { features }\end{array}$} & \multicolumn{14}{|c|}{ Identified interactional features in pre- and post- workshop classroom discourse } \\
\hline & Pre- & Post & Pre- & Post & Pre- & Post & Pre- & Post & Pre- & Post & Pre- & Post & Pre- & Post \\
\hline Elaboration & 0 & 1 & 0 & 1 & 0 & 0 & 0 & 1 & 0 & 1 & 0 & 0 & 0 & 4 \\
\hline Elicit & 10 & 9 & 3 & 10 & 4 & 9 & 9 & 23 & 0 & 11 & 8 & 2 & 34 & 64 \\
\hline Recap & 2 & 5 & 1 & 2 & 0 & 1 & 1 & 1 & 0 & 0 & 0 & 1 & 4 & 10 \\
\hline Recast & 4 & 1 & 1 & 4 & 3 & 8 & 5 & 12 & 0 & 8 & 3 & 0 & 16 & 33 \\
\hline Rejection & 0 & 0 & 1 & 0 & 0 & 0 & 0 & 0 & 0 & 0 & 0 & 0 & 1 & 0 \\
\hline Repetition & 1 & 2 & 0 & 9 & 5 & 10 & 6 & 14 & 0 & 2 & 11 & 11 & 23 & 48 \\
\hline Confirmation & 4 & 3 & 1 & 15 & 5 & 15 & 8 & 30 & 0 & 8 & 5 & 4 & 23 & 86 \\
\hline Total & 21 & 21 & 7 & 41 & 17 & 43 & 29 & 81 & 0 & 30 & 27 & 18 & 101 & 234 \\
\hline Teachers & \multicolumn{2}{|l|}{ Amy } & \multicolumn{2}{|c|}{ Cathy } & \multicolumn{2}{|l|}{ Jane } & \multicolumn{2}{|c|}{ Kate } & \multicolumn{2}{|c|}{ Mike } & \multicolumn{2}{|c|}{ Patty } & \multicolumn{2}{|c|}{ All teachers } \\
\hline
\end{tabular}

Despite the obvious increases in T-S interactions, most teachers appeared to place less emphasis on S-S interactions. Instead, teachers largely modified the lesson plan that they had jointly constructed previously in the SFL workshops, resulting mainly in the removal of the pre-planned S-S interaction activities from the Modelling and Joint Negotiation of Text stages. These stages are considered to be "central to writing development" in the teachinglearning cycle, where students develop their control of the target genre through teachers' guidance and peer interactions (Humphrey and Macnaught, 2011: 100). This result thus suggests that teachers' attitudes toward S-S interactions coincided with the pre-workshop findings about teachers' concerns in employing S-S interactions in the Chinese context, and again one of the reasons why the development of learners' communicative competence, especially in writing, has been so limited.

Overall, the assessment system and curriculum seemed to be the two main contextual factors that have constrained the teachers from transforming their beliefs into practice, and ultimately remain the main barriers to the development of students' communicative competence, especially in writing. The goal of ensuring successful test performance appeared to be the strongest obstacle to introducing any new pedagogical change in the CE classes. As very limited time was assigned to teaching writing in the university syllabus, teachers were 
forced to focus on test-taking strategies and students' final written products. Joint negotiation through social interactional activities was not considered as a priority. Mike commented that the "genre pedagogy must be helpful" but "because the curriculum, with very limited time assigned to teaching writing, is the reality, we have to ensure students' writing performance in CET first" (Mike, Int 2). These remarks demonstrated the powerful effect of teachers' knowledge of their educational context on the implementation of pedagogic intervention. Nevertheless, the fact that some of the teachers demonstrated emerging growth in both their cognitions and practice in relation to successfully incorporating the genre-based pedagogy, at least to a certain extent, into such a constrained educational context indicates that the innovative pedagogy holds promise for developing students' writing competence.

\section{Conclusion}

It is clear that the professional training in the SFL genre pedagogy had a positive impact on participants' cognition about writing instruction despite several constraining factors. All six teachers generally believed that the SFL genre pedagogy was valuable to support their students' learning of writing in CE classes and the achievement of the CECR goals. However, the implementation of the genre-based lesson plans varied amongst the teachers due to the dynamic relationship that exists between their emerging beliefs concerning the genre pedagogy and their prior beliefs about writing instruction in general. Overall, their beliefs were influenced by various contextual factors (class size, curriculum, assessment) that constrained the degree to which the teachers felt empowered to incorporate the genre pedagogy into their lessons. These factors also limited how the teachers implemented the Joint Construction stage regardless of how favourably they viewed its value. However, for some teachers (e.g. Mike's and Kate's), it is evident that their limited attention to the social purpose of constructing texts remained unchanged. Hence, in order to support teachers in 
their overall desire to apply the genre pedagogy in their classrooms, professional development on how to accomplish this in the current education system is certainly needed. Providing teachers with additional time to integrate the genre pedagogy into their writing lessons is also necessary. Finally, it is worth considering whether greater weight should be given to writing competence development in the $\mathrm{CE}$ curriculum so that the teachers have greater opportunity to put their beliefs into actual practice.

This study has implications concerning the value of SFL genre pedagogy in numerous areas, including in classrooms of EFL contexts worldwide, TESOL-oriented teacher education problems, as well as on research on TC and EFL instruction in general. One of the limitations of this study were the time constraints involved with data collection, workshop training and implementation process due to contextual factors at the research site. Considering this limitation, future studies could expand on this research by including more teacher participants, inviting more teachers to attend the workshops, and using questionnaires to gather their perspective on the genre pedagogy. Follow-up interviews and observations of the teachers' subsequent classes to see to what extent teachers use SFL pedagogy afterwards could be additional avenues for future explorations. 


\section{References}

Baker A (2014) Exploring teachers' knowledge of L2 pronunciation techniques: Teacher cognitions, observed classroom practices and student perceptions. TESOL Quarterly, 48(1): 136-163.

Borg S (1998) Teachers' pedagogical systems and grammar teaching: A qualitative study. TESOL Quarterly 32(1): 9-38.

Borg S (2001) Self-perception and practice in teaching grammar. ELT Journal 55(5): 21-29.

Borg S (2003) Teacher cognition in language teaching: A review of research on what language teachers think, know, believe, and do. Language Teaching 36(2): 81-109.

Callaghan M, Knapp P (1989) The discussion genre. Sydney: Metropolitan East DSP (Language and Social Power Project).

Callaghan M, Rothery J (1988) Teaching Factual Writing: A Genre Based Approach. Sydney, NSW: Metropolitan East Region.

Chaisiri T (2010) An investigation of the teaching of writing with a specific focus on the concept of genre. The International Journal of Learning 17(2): 195-205.

Chen Y, Su S (2012) A genre-based approach to teaching EFL summary writing. ELT Journal 66(2): 184-192.

Cheng L (2008) The key to success: English language testing in China. Language Teaching 25(1): 1537.

Chu L, Gao P (2006) An empirical study of the washback of the CET-4 writing. Sino-US English Teaching 29(3): 36-38.

Cundale N (2001) Do we practice what we preach? Stated beliefs about communicatvie language teaching and classroom questioning strategies. Language Teacher 25(5): 4-9.

Deng L, Chen Q, Zhang Y (2014) Developing Chinese EFL Learners' Generic Competence: A Genrebased and Process Genre Approach. Berlin: Springer Heidelberg.

Derewianka B (1990) Exploring How Texts Work. Rozelle, NSW: Primary English Association.

Derewianka B (2003) Trends and issues in genre-based approaches. RELC Journal 34(2): 133-154.

$\mathrm{Du} \mathrm{H}$ (2002) An investigation of College English teaching in four universities in China. International Education Journal 3(2): 71-84.

Emilia E (2005) A critical genre-based approach to teaching academic writing in a tertiary EFL context in Indonesia PhD Thesis, The University of Melbourne, Australia.

Farrell TSC, Lim PCP (2005) Conceptions of grammar teaching: A case study of teachers' belief and classroom practices. TESL-EJ 9(2): 1-13.

Gall MD, Gall JP, Borg WR (2007) Educational Research: An Introduction (8th ed.). Boston, Mass; London: Pearson.

Gao J (2007) Teaching writing in Chinese universities: Finding an eclectic approach. Asian EFL Journal 20.

Gao J, Huang J (2010) On communicative competence in curriculum design: A comparison of the College English Curriculum Requirements and the English Curriculum Standards. Polyglossia 18: 7386.

Hardman J, A-Rahman N (2014) Teachers and the implementation of a new English curriculum in Malaysia. Language, Culture and Curriculum 27(3): 260-277.

Hammond J, Gibbons P (2005) Putting scaffolding to work: The contribution of scaffolding in articulating ESL education. Prospect 20(1): 6-30.

$\mathrm{Hu}$ G (2002) Potential cultural resistance to pedagogical imports: The case of communicative language teaching in China. Language, Culture and Curriculum 15(2): 93-105.

Hu G (2007) Developing an EAP writing course for Chinese ESL students. RELC Journal 38(1): 67-86. 
Huang $\mathrm{X}$ (2001) Teaching writing through genre analysis. Avaliable at: http://www.oocities.org/winjun1118/writingweb.htm (accessed 12 January 2015).

Humphrey S, Macnaught L (2011) Revisiting joint construction in the tertiary context. Australian Journal of Language and Literacy 34(1): 99-115.

Hyland K (2003) Second Language Writing. New York: Cambridge University Press.

Hymes D (1972) On Coummunicative Competence. In: Pride JB and Holmes J (eds) Sociolinguistics. Penguin: Harmondsworth, 269-293.

Hyon S (1996). Genre in three traditions: Implications for ESL. Tesol Quarterly, 30(4): 693-722.

Ji L (2009) Genre-based approach for teaching English factual writing. Humanising Language Teaching, 11(2). Avaliable at: http://www.hltmag.co.uk/apr09/mart02.htm (accessed 27 January 2015).

Jin Y (2011) Fundamental concerns in high-stakes language testing: The case of the College English Test. Journal of Pan-Pacific Association of Applied Linguistics 15(2): 71-83.

Kang Y, Cheng X (2014) Teacher learning in the workplace: A study of the relationship between a novice EFL teacher's classroom practices and cognition development. Language Teaching Research 18(2): 169-186.

Krisnachinda S (2006) A case study of a genre-based approach to teaching writing in a tertiary context in Thailand. EdD Thesis, University of Melbourne, Australia.

Martin JR (1999) Mentoring semogenesis: 'Genre-based' literacy pedagogy. In: Frances C (ed) Pedagogy and the Shaping of Consciousness: Linguistic and Social Process. London: Cassell, 123-155.

Martin JR (2009) Genre and language learning: A social semiotic perspective. Linguistics and Education 20: 10-21.

Mercer N (1995) The Guided Construction of Knowledge: Talk Amongst Teachers and Learners. England: Clevedon, Avon.

Myskow G, Gordon K (2009) A focus on purpose: Using a genre approach in an EFL writing class. ELT Journal 64(3): 283-292.

Nation ISP, Macalister J (2010) Language Curriculum Design. Taylor and Francis.

Orafi SMS and Borg S (2008) Intentions and realities in implementing communicative curriculum reform. System 37: 243-253.

Patton MQ (2002) Qualitative Evaluation and Research Methods. Thousand Oaks, Calif: Sage Publications.

Peng Y (2011) The new teaching requirements and the influences of assessment: A case study of College English reforms in China. PhD Thesis, University of Huddersfield, UK.

Qian X (2010) A balanced approach to the teaching of intermediate-level writing skills to EFL students. English Language Teaching 3(2): 13-16.

Rahimi S (2014) Teacher cognition vis-â-vis vocabulary teaching. Theory and Practice in Language Studies 4(3): 652-660.

Richard JC (1985) New Trends in the Teaching of Writing in ESL/EFL. In: The ELT in China: The International Symposium on Teaching English in the Chinese Context, Beijing, China.

Richardson V (1996) The role of attitudes and beliefs in learning to teach. In: Sikula JP, Buttery TJ, Guyton E (eds) Handbook of Research on Teacher Education: A Project of the Association of Teacher Educators. New York: Macmillian Library Reference, 102-119.

Rozimela Y (2005) Genre-based pedagogy for teaching English academic writing in an Indonesian tertiary context: A case study. $\mathrm{PhD}$ Thesis, The University of Melbourne, Autralia.

Tian C (2005) Yinyü xiezuo jiaoxüe guocheng ticaifa yanjiu [Research on process-genre approach in teaching of English writing]. Master's Thesis, East China Normal University, China.

Wang C (2013) A study of genre approach in EFL writing. Theory and Pracitce in Language Studies 3(11): 2128-2135. 
Wang W, Gao X (2008) English language education in China: A review of selected research. Journal of Multilingual and Multicultural Development 29(5): 380-399.

Wu Y (2001) English language teaching in China: Trends and challenges. Tesol Quarterly 35(1): 191194.

Yü L (2001) Communicative language teaching in China: Progress and resistance. TESOL Quarterly 35(1): 194-198.

Yan Y (2010) Towards an eclectic framework for teaching EFL writing in a Chinese context. US-China Education Review 7(3): 29-33.

Yin RK (2003). Case Study Research: Design and Methods. Thousand Oaks, Calif: Sage Publications. You X (2004a) "The choice made from no choice": English writing instruction in a Chinese university. Journal of Second Language Writing 13: 97-110.

You X (2004b) New directions in the EFL writing: A report from China. Journal of Second Language Writing 13: 254-256.

Zhang F, Liu Y (2013) A study of secondary school English teachers' beliefs in the context of curriculum reform in China. Language Teaching and Research 0(0): 1-18.

Zhang Y (2006) A study on college students response to writing conferences. CELRA Journal 29(3): 24-28. 


\section{APPENDIX A}

Interview Questions with Teachers

Time Date

Participant's Name

\section{Pre-interview Interview Questions}

\section{The CECR, the CLT and the assessment}

1. In one or two sentences, how would you describe the main goal of the current College English Curriculum (CECR)?

能否用你自己的话描述一下目前大英课程 大纲要求 (以下简称“要求”) 中的主要教 学目标?

2. To meet the objective of "developing students' ability to use English in a well-rounded way to communicate effectively" in CECR, what language skills are required in your view?

- What is the most important one?

- How important is the role of the writing competence?

3. Can you describe how writing is assessed in achievement tests such as mid-term tests or final tests? Why is that the way?

根据‘培养学生的英语综合应用能力最终达 到能有效进行交际'的大学英语教学目标, 你认为其中包含哪些英语能力要求?

- 其中哪个语言能力是最重要的?

- 写作能力是怎样的角色?

\section{Current classroom teaching of writing}

4. How much time does teaching of writing occupy in your College English classroom? Why?

5. How is writing normally taught in your classroom? Can you give me some examples?

6. What text types do you normally teach? Why?

7. What are the difficulties in teaching writing? And what makes it easier to teach writing?

在大学英语教学中, 写作教学时间大概占 用多少? 为什么?

在你的大学英语课上, 你一般是如何教写 作的? 能否举一些例子?

\section{Students' needs in learning of writing}

8. In your view, what are your students' writing $\quad$ 你觉得学生写作方面有哪些需要, 又有哪 needs and difficulties?

9. What are their attitudes towards learning of writing? 些难点?

学生对学习写作一般持怎样的态度?

\section{Teachers' educational background and professional experiences}

10. Can you tell me about your educational background and professional experiences?

- What professional development activities with regard to teaching writing have you been involved in?

- Recalling your training and professional experiences, what do you wish you had known more about regarding the teaching of writing?

11. Do you think our teachers' teaching of writing
能不能简单介绍一些关于你教育以及培训 背景（譬如说）

- 你曾经参加过哪些和写作教学有关的 专业培训?

- 回顾你所经历的专业培训和教学经 验, 你觉得还有哪些跟写作教学相关 的方面希望了解的?

你认为我们老师们在进行写作教学时是不 


\begin{tabular}{|c|c|}
\hline $\begin{array}{l}\text { is informed by writing theories? If yes, what are } \\
\text { the main ones? If not, why not? } \\
\text { writing? Wow do you choose strategies when teaching } \\
\text { - Do you geet them? } \\
\text { would help teachers to better support students in } \\
\text { developing their writing competence? If yes, what type } \\
\text { of workshops? }\end{array}$ & $\begin{array}{l}\text { 是用一些写作理论作指导? 如果是的话, } \\
\text { 你觉得哪些理论比较流行呢? 如果不是的 } \\
\text { 话, 你觉得是什么原因呢? } \\
\text { - 在教写作时, 你是如何选择教学方法 } \\
\text { 的? 你是如何知道这些方法的? } \\
\text { - 你觉得哪些种类的专业培训可以有助 } \\
\text { 于老师们更好地帮助学生达到《要 } \\
\text { 求》中关于写作的目标? }\end{array}$ \\
\hline
\end{tabular}

\begin{tabular}{|c|c|}
\hline \multicolumn{2}{|c|}{ Post-workshop Interview Questions } \\
\hline $\begin{array}{l}\text { 1. Did you enjoy the way of teaching the lesson? } \\
\text { What worked well for you? } \\
\text { Did you encounter any difficulties? } \\
\text { What is your opinion of the lesson plan? e.g. } \\
\text { - The choice and sequence of the activities } \\
\text { - Classroom organization } \\
\text { - The way of interacting with the students (we } \\
\text { called it scaffolding - remember?) } \\
\text { The choice of resources used in class }\end{array}$ & $\begin{array}{l}\text { 你是否喜欢这节课上的教学方法? 哪些方 } \\
\text { 面你觉得效果较好? 你是否也遇到一些疑 } \\
\text { 难? 你如何评价这个教学计划? 比如说 } \\
\text { - 课堂活动、步骤的选择 } \\
\text { - 课堂的组织 } \\
\text { - 学生小组活动的方式 } \\
\text { - 和学生互动的方式 (我们称之为 } \\
\text { scaffolding 的, 记得吗?) } \\
\text { - 教学所需要的辅助材料的选择 }\end{array}$ \\
\hline $\begin{array}{l}\text { 2. What do you think about the use of model text } \\
\text { in introducing a target genre? What do you think } \\
\text { your students have learned from the model? }\end{array}$ & $\begin{array}{l}\text { 在这次课上, 你用范文形式向学生介绍了 } \\
\text { 所要学习的写作体裁。能否谈谈使用这种 } \\
\text { 方法的体会? 你觉得学生从范文介绍过程 } \\
\text { 中学到了什么? }\end{array}$ \\
\hline $\begin{array}{l}\text { 3. What do y } \\
\text { groups to } \mathrm{w} \\
\text { stage of Joir }\end{array}$ & $\begin{array}{l}\text { 你对于安排学生一起写文章的过程是怎样 } \\
\text { 的体会（我们称之为合作写作）? }\end{array}$ \\
\hline $\begin{array}{l}\text { 4. How did you support your students during various } \\
\text { times of the lesson? How did you interact with } \\
\text { them? Were there any differences in this lesson to } \\
\text { how you did it before? How do you feel about the } \\
\text { outcomes of... (observed activities/strategies)? }\end{array}$ & $\begin{array}{l}\text { 在不同的课堂时间段中, 你是如何帮助学 } \\
\text { 生的? 你是如何和他们互动的? 给学生提 } \\
\text { 供相应的帮助的? 和之前的课相比, 这堂 } \\
\text { 课上你是否采用了一些不一样的方法呢? } \\
\text { 对于像 (所观察到的活动/方法), 你对于 } \\
\text { 他们的结果感觉如何? }\end{array}$ \\
\hline $\begin{array}{l}\text { 5. What do you think of the achie } \\
\text { of the lesson? Do you think you } \\
\text { made some improvement in cer } \\
\text { taught such as 'text structure' ar } \\
\text { features'? Why?/Why not? }\end{array}$ & $\begin{array}{l}\text { 你自己对这整堂课的效果怎么评价? 你是 } \\
\text { 否觉得在这堂课上学生有所提高, 特别是 } \\
\text { 因为你对一些特定方面的教学, 比如说“文 } \\
\text { 章结构”, “语言使用特征”等。为什么你这 } \\
\text { 么认为? }\end{array}$ \\
\hline $\begin{array}{l}\text { 6. What are the advantages and limitations of this } \\
\text { genre pedagogy in your view? }\end{array}$ & 你觉得这种体裁法的优点和局限性是什么? \\
\hline $\begin{array}{l}\text { 7. In general, do you think this pedagogy is practical } \\
\text { in assisting Chinese EFL teachers to help their } \\
\text { students develop their writing competence? } \\
\text { Why/Why not? }\end{array}$ & $\begin{array}{l}\text { 总的来说, 你觉得采用这种体裁教学法是 } \\
\text { 否有助于我们中国的大学英语老师们帮助 } \\
\text { 他们的学生提高写作交际能力? 为什么/为 }\end{array}$ \\
\hline
\end{tabular}




\begin{tabular}{|c|c|}
\hline & 什么不? \\
\hline $\begin{array}{l}\text { 8. If you are to teach such a lesson again what } \\
\text { adjustments need to be made? Are you going to } \\
\text { add something or take out, or change a sequence? } \\
\text { Or re-arrange? }\end{array}$ & $\begin{array}{l}\text { 如果你再上这样一堂课的话你认为需要作 } \\
\text { 哪些调整? 你会怎加或者删除一些呢, 还 } \\
\text { 是改变一下步骤? 或者重新组织一下? 有 } \\
\text { 帮助的话, 是否需要作一些调整, 该如何 } \\
\text { 调整? }\end{array}$ \\
\hline
\end{tabular}


APPENDIX B

Classroom Observation Notes

Class Teacher

Date

Topic

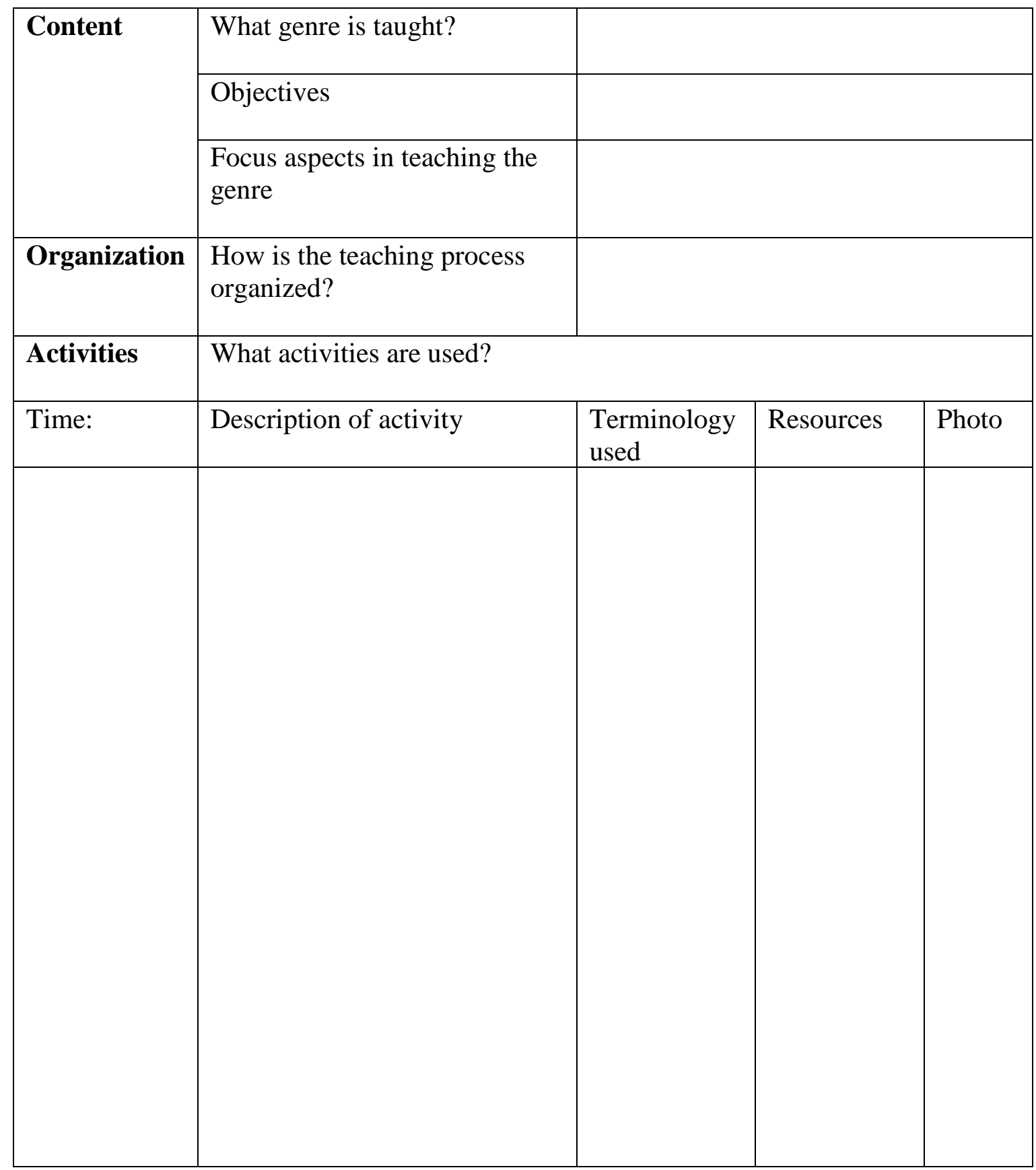

